\title{
Comment on "Regulation of immunity during visceral Leishmania infection" and further discussions about the role of antibodies in infections with Leishmania
}

\author{
Luiz Gustavo Gardinassi* and Isabel Kinney Ferreira de Miranda Santos
}

\begin{abstract}
Comments on the article "Regulation of immunity during visceral Leishmania infection" published in Parasites \& Vectors 2016, 9:118, and further discussions about the role of antibodies in infections with Leishmania.
\end{abstract}

Keywords: Leishmaniasis, Antibodies, Fc receptors, Fc N-glycosylation, Immunopathology, Protection

\section{Letter to the editor}

Rodrigues and colleagues recently presented in this journal a comprehensive and timely review of the current state of knowledge about immunity to visceralizing species of Leishmania in humans and in animal models [1]. We read with particular interest the topic they devoted to studies that evaluated the role of antibodies, B cells and $\mathrm{T}$ follicular helper cells during infections with these intracellular parasites. We strongly agree with the authors' conclusions about the need to reassess the role of antibodies in these infections, wherein they state that "Rather than considering the role of antibodies solely as pathological or irrelevant, it is perhaps wiser to acknowledge that these molecules may play both protective and non-protective roles during VL". However, we would like to add further information from studies that provide important evidence and concepts that also support a crucial role of antibodies during infections with Leishmania and that were not considered in their review.

As pointed out by Arturo Casadevall, the rationale for dichotomizing types of immunity against extracellular and intracellular pathogens into antibody-mediated and cell-mediated, respectively, is based on concepts that probably originated in the great debate between scientists advocating humoral or cellular immunity at the beginning of the 20th century [2]. However, this concept cannot be

\footnotetext{
* Correspondence: gustavogardinassi@usp.br; imsantos@fmrp.usp.br Departamento de Bioquímica e Imunologia, Faculdade de Medicina de Ribeirão Preto, Universidade de São Paulo, Ribeirão Preto, São Paulo, Brazil
}

applied to every known pathogen, whereby antibodies have been shown to protect against at least some intracellular pathogens such as Trypanosoma cruzi [3, 4], Histoplasma capsulatum [5] and Mycobacterium tuberculosis [6]. Since the majority of early studies on the leishmaniases did not correlate antibody-mediated immunity with protection, many questions about the role of B lymphocytes and antibodies during such infections remained unanswered. However, an initial proof of concept that antibodies can be important for controlling infections with Leishmania comes from the observation that pathogenic Trypanosomatidae express receptors for IgG Fc [7, 8] or proteases for IgG [9], possibly to escape from this effector mechanism.

In the early 80's Anderson and colleagues [10] demonstrated that the protective effect of a monoclonal antibody raised against $L$. mexicana was dependent on the number of antibody-opsonized parasites inoculated into BALB/c mice [10]. Furthermore, another study showed that monoclonal antibodies raised against L. infantum conferred passive cross-protection against infections with L. amazonensis and L. major in mice [11]. As addressed by Rodrigues and colleagues [1], a study demonstrated that protective immunity against $L$. major required efficient uptake of IgG-opsonized parasites by dendritic cells through Fc-gamma receptors (Fc $\gamma \mathrm{R})$ I and III [12]. More recent work revealed that elimination of L. amazonensis depends in part on the FcyR common-chain and NADPH oxidasegenerated superoxide from infected macrophages in vitro 
[13]. In contrast, a study showed that interactions of mouse IgG1 with FcyRIII is detrimental in infections with $L$. mexicana, but not interactions with $\operatorname{IgG} 2 \mathrm{a} / \mathrm{c}$ or IgG3 [14]. Together, these data suggest that the signaling pathways through which phagocytes are activated might be fundamental for the functional profile that these cells will acquire and, therefore, for their effects on polarizing the cell populations that will comprise Leishmania-specific acquired immunity.

Notably, mice that lack immunoglobulin-bearing B cells $(\mathrm{JhD} \mathrm{BALB/c})$ are considered to be relatively resistant to infection with $L$. pifanoi, L. amazonensis and $L$. infantum and passive transfer of B cells, immune serum or purified antibodies to chronically infected JhD BALB/c mice restored susceptibility to infection, respectively [15-17]. In addition, $\mu \mathrm{MT}$ mice (assumed to lack mature B cells) also exhibit a relative resistance when infected with L. major LV39 (BALB/c) [18] or L. donovani (C57BL/6) [19]; however, other work indicates that $\mu$-chain-deficient mice possess functional B-1 cells and can produce nonspecific IgG [20,21]. Indeed, the studies mentioned above did not discriminate between subsets of cells derived from B lymphocytes such as plasma cells, regulatory B cells or marginal zone B cells, which exhibit different functions depending on the context of infection with Leishmania [22-28]. We also highlight that, while mice (BALB/c or C57BL/6) are acutely susceptible to these parasites, they do not develop chronic and progressive disease after infection with $L$. donovani or L. infantum [29]. Therefore, the role of antibodies in these mouse models of visceral leishmaniasis (VL) and its translation into immunopathological features observed in progressive disease as seen in humans and non-human primates, dogs and hamsters, may warrant reinterpretation. Accordingly, Reis and colleagues [30] observed a strong correlation between levels of IgG1 antibodies specific for soluble antigens from $L$. infantum promastigotes and an asymptomatic outcome of infection and also a correlation between IgG2 of the same specificity and manifestation of disease in dogs. In another study, Oliveira and colleagues [31] observed that dogs presenting with asymptomatic infections with $L$. infantum have significantly lower levels of IgG2 antibodies specific for a crude antigen extract from these parasites than symptomatic dogs. Interestingly, these authors also observed that dogs vaccinated with Leishimmune ${ }^{\bullet}$ (Fort Dodge Animal Health) and supposedly protected against disease, present negligible levels of IgG1, IgG3 e IgG4 antibodies and high levels of IgG2 antibodies against this crude antigen extract.

As pointed out by Rodrigues and colleagues in their review [1], the dose of parasites may influence the resulting immune response [32]. Menon \& Bretscher [33] also determined that the dose of Leishmania affects the outcome of infection even in genetically susceptible hosts: BALB/c mice can control infection with L. major, a visceralizing parasite in this host, if they receive a low dose of parasites. Dominguez and colleagues [34] and Moreno and colleagues [35] showed that natural antibodies present in normal human sera rapidly (i.e. in $2.5 \mathrm{~min}$ ) cause lysis of 85-95\% of infective metacyclic Leishmania promastigotes by means of the classical pathway of complement. Thus, Leishmania-reactive antibodies presenting an adequate profile may result in manageable doses of parasites at crucial initial stages of infection with Leishmania by promoting lysis of infective promastigotes inoculated by vectors. This mechanism does not exclude a further role for antibodies with adequate profiles in activating microbicidal mechanisms and expansion of efficacious effector responses through appropriate signaling pathways in Leishmania-infected phagocytic and antigen-presenting cells.

Finally, we wish to point out that not only variability at the level of protein within IgG subclasses and the different FcR affects effector mechanisms of antibodymediated immunity: interactions of IgGs with type I FcR (the canonical Fc $\gamma$ RI, Fc $\gamma$ RIIa, Fc $\gamma$ RIIb, Fc $\gamma$ RIIc, Fc $\gamma$ RIIIa, FcyRIIIb) or type II FcR (DC-SIGN and CD23) [36]; or with mannan-binding lectin [37] and the complement component $\mathrm{Clq}$ [38] are also regulated by the patterns of $\mathrm{N}$-linked, biantennary glycan structures attached to Asn 297 of the IgG heavy chain [39]. In a recent study, we and our colleagues applied a robust method of IgG Fc $\mathrm{N}$-glycopeptide profiling that demonstrated profound alterations in the patterns of IgG Fc N-glycosylation of VL patients compared with those of asymptomatic individuals and non-infected controls [40]. In fact, the profile of IgG Fc glycans presented by the VL patients that we examined is compatible with and may contribute to the imbalance of the inflammatory milieu that Rodrigues and colleagues suggest is unfavorable for proper differentiation of $\mathrm{T}$ follicular helper cells [1]. In our opinion, those alterations are extremely relevant and should be considered in future studies addressing immunopathological or protective responses in infections with Leishmania, which might depend on the clinical context after infection and possibly affect bystander inflammatory processes [41], B cell activation and regulation [42] and antibody-mediated effector functions.

\section{Abbreviations}

FcyR, Fc-gamma receptor; $V L$, visceral leishmaniasis

\section{Acknowledgements}

This study was supported by a grant to I.K.F.M.S. from the Conselho Nacional de Desenvolvimento Científico e Tecnológico (CNPq grant 467608/2014-8). L.G.G. was supported by scholarships from the Fundação de Amparo à Pesquisa do Estado de São Paulo (FAPESP 2011/23819-0 and 2014/25856-8). 


\section{Funding}

Not applicable

Availability of data and material

Not applicable

\section{Authors' contributions}

LGG and IKFMS performed the review of the literature, wrote and revised the manuscript. All authors read and approved the final version of the manuscript.

\section{Competing interests}

The authors declare that they have no competing interests.

\section{Consent for publication}

Not applicable

\section{Ethics approval and consent to participate}

Not applicable

Received: 11 April 2016 Accepted: 27 June 2016

Published online: 07 July 2016

\section{References}

1. Rodrigues V, Cordeiro-da-Silva A, Laforge M, Silvestre R, Estaquier J. Regulation of immunity during visceral Leishmania infection. Parasit Vectors. 2016;9:118.

2. Casadevall A. Antibody-mediated immunity against intracellular pathogens: two-dimensional thinking comes full circle. Infect Immun. 2003;71(8):4225-8.

3. Plata F, Wietzerbin J, Pons FG, Falcoff E, Eisen H. Synergistic protection by specific antibodies and interferon against infection by Trypanosoma cruzi in vitro. Eur J Immunol. 1984;14(10):930-5.

4. Umekita LF, Ramos DP, Mota I. Clearance-inducing antibodies are responsible for protection against the acute phase of Trypanosoma cruzi infection in mice. Braz J Med Biol Res. 1997:30(10):1191-7.

5. Nosanchuk JD, Steenbergen JN, Shi L, Deepe GS, Casadevall A. Antibodies to a cell surface histone-like protein protect against Histoplasma capsulatum. J Clin Invest. 2003;112(8):1164-75.

6. Abebe F, Bjune $\mathrm{G}$. The protective role of antibody responses during Mycobacterium tuberculosis infection. Clin Exp Immunol. 2009;157(2):235-43.

7. De Miranda-Santos IK, Campos-Neto A. Receptor for immunoglobulin Fc on pathogenic but not on nonpathogenic protozoa of the Trypanosomatidae. J Exp Med. 1981;154(6):1732-42.

8. Campos-Neto A, Suffia I, Cavassani KA, Jen S, Greeson K, Ovendale P, et al. Cloning and characterization of a gene encoding an immunoglobulin-binding receptor on the cell surface of some members of the family Trypanosomatidae. Infect Immun. 2003;71(9):5065-76.

9. Berasain P, Carmona C, Frangione B, Cazzulo JJ, Goñi F. Specific cleavage sites on human IgG subclasses by cruzipain, the major cysteine proteinase from Trypanosoma cruzi. Mol Biochem Parasitol. 2003;130(1):23-9.

10. Anderson S, David JR, McMahon-Pratt D. In vivo protection against Leishmania mexicana mediated by monoclonal antibodies. J Immunol. 1983; 131(4):1616-8

11. Debons-Guillemin MC, Vouldoukis I, Roseto A, Alfred C, Chopin C, Ploton I, et al. Inhibition in vivo of both infective Leishmania major and L. mexicana amazonensis mediated by a single monoclonal antibody. Trans R Soc Trop Med Hyg. 1986;80(2):258-60.

12. Woelbing F, Kostka SL, Moelle K, Belkaid Y, Sunderkoetter C, Verbeek S, et al. Uptake of Leishmania major by dendritic cells is mediated by Fcgamma receptors and facilitates acquisition of protective immunity. J Exp Med. 2006:203(1):177-88.

13. Gibson-Corley KN, Bockenstedt MM, Li H, Boggiatto PM, Phanse Y, Petersen CA, et al. An in vitro model of antibody-enhanced killing of the intracellular parasite Leishmania amazonensis. PLoS One. 2014;9(9):e106426.

14. Chu N, Thomas BN, Patel SR, Buxbaum LU. IgG1 is pathogenic in Leishmania mexicana infection. J Immunol. 2010;185(11):6939-46.

15. Colmenares M, Constant SL, Kima PE, McMahon-Pratt D. Leishmania pifanoi pathogenesis: selective lack of a local cutaneous response in the absence of circulating antibody. Infect Immun. 2002;70(12):6597-605.

16. Wanasen $N$, Xin L, Soong L. Pathogenic role of B cells and antibodies in murine Leishmania amazonensis infection. Int J Parasitol. 2008;38(3-4):417-29.
17. Deak E, Jayakumar A, Cho KW, Goldsmith-Pestana K, Dondji B, Lambris JD, et al. Murine visceral leishmaniasis: IgM and polyclonal B-cell activation lead to disease exacerbation. Eur J Immunol. 2010;40(5):1355-68.

18. Ronet C, Voigt H, Himmelrich H, Doucey M-A, Hauyon-La Torre $Y$, Revaz-Breton $M$, et al. Leishmania major-specific B cells are necessary for Th2 cell development and susceptibility to L. major LV39 in BALB/C mice. J Immunol. 2008;180(7):4825-35.

19. Smelt SC, Cotterell SE, Engwerda CR, Kaye PM. B cell-deficient mice are highly resistant to Leishmania donovani infection, but develop neutrophilmediated tissue pathology. J Immunol. 2000;164(7):3681-8.

20. Hasan M, Polic B, Bralic M, Jonjic S, Rajewsky K. Incomplete block of B cell development and immunoglobulin production in mice carrying the $\mu$ MT mutation on the BALB/c background. Eur J Immunol. 2002;32(12):3463-71.

21. Ghosh S, Hoselton SA, Schuh JM. Mu-deficient mice possess B1 cells and produce lgG and lgE, but not lgA, following systemic sensitization and inhalational challenge in a fungal asthma model. J Immunol. 2012;189(3):1322-9.

22. Bankoti R, Gupta K, Levchenko A, Stäger S. Marginal zone B cells regulate antigen-specific $T$ cell responses during infection. J Immunol. 2012:188(8):3961-71.

23. Rodriguez-Pinto D, Saravia NG, McMahon-Pratt D. CD4 T cell activation by B cells in human Leishmania (Viannia) infection. BMC Infect Dis. 2014;14:108.

24. Rodrigues V, Laforge M, Campillo-Gimenez L, Soundaramourty C, Correia-de-Oliveira A, Dinis-Oliveira RJ, et al. Abortive T follicular helper development is associated with a defective humoral response in Leishmania infantum-infected macaques. PLoS Pathog. 2014;10(4):e1004096.

25. Gonzaga WFKM, Xavier V, Vivanco BC, Lopes JD, Xander P. B-1 cells contribute to susceptibility in experimental infection with Leishmania (Leishmania) chagasi. Parasitology. 2015;142(12):1506-15.

26. Andreani G, Ouellet M, Menasria R, Gomez AM, Barat C, Tremblay MJ. Leishmania infantum amastigotes trigger a subpopulation of human B cells with an immunoregulatory phenotype. PLoS Negl Trop Dis. 2015;9(2):e0003543.

27. Arcanjo AF, LaRocque-de-Freitas IF, Rocha JDB, Zamith D, Costa-da-Silva AC, Nunes MP, et al. The PGE2/IL-10 axis determines susceptibility of B-1 cell-derived phagocytes (B-1CDP) to Leishmania major infection. PLoS One. 2015;10(5):e0124888

28. Silva-O'Hare J, de Oliveira IS, Klevorn T, Almeida VA, Oliveira GGS, Atta AM, et al. Disruption of splenic lymphoid tissue and plasmacytosis in canine visceral leishmaniasis: changes in homing and survival of plasma cells. PLoS One. 2016;11(5):e0156733.

29. Sacks DL, Melby PC. Animal models for the analysis of immune responses to leishmaniasis. Curr Protoc Immunol. 2015. doi:10.1002/0471142735. im1902s108

30. Reis AB, Teixeira-Carvalho A, Vale AM, Marques MJ, Giunchetti RC, Mayrink W, et al. Isotype patterns of immunoglobulins: hallmarks for clinical status and tissue parasite density in Brazilian dogs naturally infected by Leishmania (Leishmania) chagasi. Vet Immunol Immunopathol. 2006;112(3-4):102-16.

31. Oliveira TMFS, Mineo TWP, Bason M, Day MJ, Machado RZ. IgG subclass profile of serum antibodies to Leishmania chagasi in naturally infected and vaccinated dogs. Vet Parasitol. 2009;162(1-2):16-22.

32. Kaur S, Kaur T, Garg N, Mukherjee S, Raina P, Athokpam V. Effect of dose and route of inoculation on the generation of CD4+ Th1/Th2 type of immune response in murine visceral leishmaniasis. Parasitol Res. 2008;103(6):1413-9.

33. Menon JN, Bretscher PA. Parasite dose determines the Th1/Th2 nature of the response to Leishmania major independently of infection route and strain of host or parasite. Eur J Immunol. 1998;28(12):4020-8.

34. Domínguez M, Moreno I, López-Trascasa M, Toraño A. Complement interaction with trypanosomatid promastigotes in normal human serum. J Exp Med. 2002;195(4):451-9.

35. Moreno I, Molina R, Toraño A, Laurin E, García E, Domínguez M. Comparative real-time kinetic analysis of human complement killing of Leishmania infantum promastigotes derived from axenic culture or from Phlebotomus perniciosus. Microbes Infect Inst Pasteur. 2007;9(14-15):1574-80.

36. Pincetic A, Bournazos S, DiLillo DJ, Maamary J, Wang TT, Dahan R, et al. Type I and type II Fc receptors regulate innate and adaptive immunity. Nat Immunol. 2014;15(8):707-16.

37. Malhotra R, Wormald MR, Rudd PM, Fischer PB, Dwek RA, Sim RB. Glycosylation changes of IgG associated with rheumatoid arthritis can activate complement via the mannose-binding protein. Nat Med. 1995:1(3):237-43.

38. Quast I, Keller CW, Maurer MA, Giddens JP, Tackenberg B, Wang L-X, et al. Sialylation of lgG Fc domain impairs complement-dependent cytotoxicity. J Clin Invest. 2015;125(11):4160-70. 
39. Zauner G, Selman MHJ, Bondt A, Rombouts Y, Blank D, Deelder AM, et al. Glycoproteomic analysis of antibodies. Mol Cell Proteomics MCP. 2013;12(4):856-65.

40. Gardinassi LG, Dotz V, Hipgrave Ederveen A, de Almeida RP, Nery Costa CH, Costa DL, et al. Clinical severity of visceral leishmaniasis is associated with changes in immunoglobulin g fe N-glycosylation. mBio. 2014;5(6):e01844-14.

41. Karsten CM, Pandey MK, Figge J, Kilchenstein R, Taylor PR, Rosas M, et al. Anti-inflammatory activity of IgG1 mediated by Fc galactosylation and association of FcyRIIB and dectin-1. Nat Med. 2012;18(9):1401-6.

42. Hess C, Winkler A, Lorenz AK, Holecska V, Blanchard V, Eiglmeier S, et al. T cell-independent B cell activation induces immunosuppressive sialylated lgG antibodies. J Clin Invest. 2013;123(9):3788-96.

Submit your next manuscript to BioMed Central and we will help you at every step:

- We accept pre-submission inquiries

- Our selector tool helps you to find the most relevant journal

- We provide round the clock customer support

- Convenient online submission

- Thorough peer review

- Inclusion in PubMed and all major indexing services

- Maximum visibility for your research

Submit your manuscript at www.biomedcentral.com/submit
Biomed Central 